not attracted by the school of E. Mach nor that of the dialectical materialists which is discussed at the end of this volume. Indeed, his theological beliefs were an essential part of his outlook. Not only did they influence his epistemological tenets, but they sustained in him that mixture of dignity and poise which were the outward signs of a lively faith. Through it he triumphed over his personal tragedies and sorrows.

It is instructive to contemplate Planck as a teacher. How different, for example, from Arnold Sommerfeld with his brilliant circle at Munich, where Planck had been at school. No large following developed at Berlin, though the early death of Von Mosengeile robbed science of a pupil of outstanding promise. As with some other master minds, Planck seemed to have needed "cobrilliance" if progress with research students was to occur.

Some of the most interesting material before us is contained in a running conversation between Planck and his friend Hartmann in 1935. They talked about everything on Earth including the preliminaries to atomic fission, in which context Hahn's work became known in 1938. Here indeed was the true philosopher, ready to acknowledge that metaphysics may well advance, if common cause is made with natural knowledge.

A moral of all this is plain, especially for academic critics and reformers. We evaluate university efficiency, productivity and so on at our peril. The sheer achievement of one Max Planck makes nonsense of all attempts to measure the gift of learning, or to force it into Procrustean beds made for more ordinary mortals to sleep in.

F. I. G. RawLINS

\section{MAPPING WEATHER}

\section{British Weather in Maps}

Second edition. By James A. Taylor and R. A. Yates. Pp. $x v+315$. (London: Macmillan and Co., Ltd.; New York: St Martin's Press, 1967.) 50s. net.

THIS book introduces the reader to the most interesting, the most complex, and probably the most expensive document issued daily by Her Majesty's Governmentthe daily weather report. It is intended for the student rather than for the general reader, and accepts what is surely one of the soundest pedagogical principles, that to achieve some degree of rapport with numerical material the student must be encouraged to manipulate it himself. Twenty selected weather situations are presented with admirable clarity and a method is illustrated by which each complex picture may be broken down into some of its component parts. No really specialized knowledge is called for, but patient application is assumed and it is surely hoped that both interest and some degree of awareness will follow. That this is not, in fact, the way our forecasters work is entirely irrelevant. Their job is done before the report goes to press.

For the first 240 pages the page-numbering of the second edition is identical with that of the first and the situations analysed are unchanged. The two editions can therefore be used together in class. Many of the upperair insets have been improved, however, as also have a number of the explanatory figures in the text. A new chapter on "Classifications of British Weather and Climate" has been added, although the impression left on me is that the exercise, however desirable, still seems to be both exasperating and, at second hand, unrewarding. The fun is in the attempt rather than in the achievement.

It is a sad comment on rising costs that the price of the present volume is well over twice that of the original edition, though that was certainly remarkable value for money.

\section{CORRESPONDENCE}

\author{
How Insects Hear
}

SIR,--An evolutionary thought on the variety of hearing organs in nocturnal insects.

\author{
In days of old and insects bold \\ (Before bats were invented), \\ No sonar cries disturbed the skies-- \\ Moths flew uninstrumented.
}

The Eocene brought mammals mean ${ }^{1}$ And bats began to sing; Their food they found by ultrasound And chased it on the wing ${ }^{2}$.

Now deafness was unsafe because The loud high-pitched vibration Came in advance and gave a chance To beat echolocation ${ }^{3}$.

Some found a place on wings of lace To make an ear in haste ${ }^{4}$; Some thought it best upon the chest ${ }^{5}$ And some below the waist ${ }^{6}$.

Then Roeder's key upon the breeze Made Sphingids show their paces. He found the ear by which they hear In palps upon their faces?

Of all unlikely places !

Yours faithfully,

Department of Zoology,

$$
\text { J. D. PyE }
$$

King's College, Strand, WC2.

1 Jepsen, G. L., Science, 154, 1333 (1966). Early Eocene Bat from Wyoming. ${ }^{2}$ Griffin, D. R., Listening in the Dark (Yale University Press, New Haven, 1958)

${ }^{3}$ Roeder, K. D., and Treat, A. E., Amer. Sci., 49, 135 (1961). The Detection and Evasion of Bats by Moths.

${ }^{4}$ Miller, L. A., and MacLeod, E. G., Science, 154, 891 (1966). Ultrasonic Sensitivity: a Tympanal Receptor in the Green Lace Wing Chrysopa carnea.

${ }^{5}$ Roeder, K. D., and Treat, A. E., J. Exp. Zool., 134, 127 (1957). Ultrasonic Reception by the Tympanic Organ of Noctuid Moths.

- Belton, P., Nature, 196, 1188 (1962). Responses to Sound in Pyralid Moths.

" Roeder, K. D., Treat, A. E., and Vandeberg, J. S., Science, 159, 331 (1968). Auditory Sense in Certain Sphingid Moths.

\section{New Name for the Kilogram}

Sir,-Attention was drawn by C. W. Allen (Nature, $218,209 ; 1968)$ to the absurdity of having the multiple name kilogram for a fundamental unit in the SI system of units. After a search through the alphabet, now names and symbols for the kilogram were suggestedbar(r)am, qur(r)am, abbreviated b or q-for a smoother introduction of the SI system. The author pointed to the possibility of confusion with other well used units and prefix symbols and, in particular, rejected the symbol k.

I agree with Allen's objections to the name kilogram. However, I do not see a real chance that these new names will ever be accepted, since they too completely abandon the currently used symbols and names. I therefore suggest the alternative that "kilo" should be chosen as the name for the unit and $\mathbf{k}$ as its abbreviation. Fractions and multiples should be formed in the standard way: $\mathrm{mk}$ (millikilo) for $\mathrm{g}, \mu \mathrm{k}$ (microkilo) for $\mathrm{mg}$, and, consequently, $\mathrm{kk}$ (kilokilo) for a thousand $\mathrm{kg}$. The unit k, used by itself, could not cause confusion with the prefix $k$, as prefixes are not used alone. Nor does confusion arise between $\mathrm{m}$ as $a$ unit and $\mathrm{m}$ as a prefix. In $\mathrm{mm}$ the first and second $m$ have different meanings. Nobody feels embarrassment 